\title{
ADAPTATION OF FLOURISHING AS POSITIVE PSYCHOLOGY CONCEPT IN LATVIA
}

\author{
Ieva Pakse, Guna Svence \\ University of Latvia, Latvia \\ E-mail: guna.svence@lu.Iv
}

\begin{abstract}
The aim of the study is to adapt linguistically and psychometrically the construct of flourishing and to compare four most popular measuring instruments by looking at their psychometric validity indicators and examining in more details the flourishing level of randomized sample in Latvia $(N=312)$. As this construct was not adapted in Latvia jet, it is a new concept both - in terms of content and psychometry. Therefore, the tasks of research were more related to the study of the construct's own content by comparing most popular flourishing measuring instruments, their internal consistency, analyzing the convergent validity of measuring instruments, and studying of the relationships between various demographic indicators and the level of flourishing. The research results confirm that flourishing scores of all four measuring instruments mutually correlate, that suggests cross compliance of all four instruments. Demographic indicators as education and occupation are the only ones which are mathematically plausible, but only at trend level correlate with flourishing characteristics. The data adapted in the study and psychometrically tested methodologies can be used in the practice of psychologists and in other studies in the future. The discussion raised the question of why neither gender nor age correlate with flourishing, that contradicts other similar studies in the word.
\end{abstract}

Keywords: flourishing characteristics, measuring instruments, positive psychology, well-being

\section{Introduction}

Flourishing is a research issue that is increasingly being addressed both by theorists and practical research authors related to public mental health. Whereas research in positive psychology has already been carried out in Latvia for a long time (Svence \& Majors, 2015; Svence \& Majors, 2016, Svence, 2015, Svence \& Seglina-Gluškova, 2014), then as a continuation - the new construct of flourishing was adapted as well. In psychology of Latvia and Baltic States this construct is the new one, while in context of European countries and the world it enriches the topic of the mental health.

The World Health Organization has identified the promotion of health as a key objective in medicine, while health is defined as the physical, psychological, and social well-being of the individual (WHO, 1946, WHO 2013). Therefore, it can be said that individual's life and personality well-being is at the heart of society's survival, living, welfare and health. National governments are encouraged to focus on positive psychology as a way of thinking that can be learned, because it is not enough that only separate individuals are happy and satisfied with life. It is important that the idea is developed at a national level (Hone et al., 2014). 
OF PSYCHOLOGY

IN THE $21^{\text {st }}$ CENTURY Vol. 14, No. 2, 2020

114

Although the number of publications about flourishing is not large, it has been growing since 2009. For example, on the internationally recognized publication site of scientific psychological articles APA Psych NET, in 2017 there were 14 articles, 2018 - 6, but in 2020 there are 30 articles already. The articles are devoted to both - general research and analysis of the concepts (for example, Titova et al., 2018), analysis of specific situations from the perspective of psychological flourishing (Munoz et al., 2019, Perera et al, 2018), regional analysis (Lipovčan et al., 2018, Jankowski et al., 2020), and in connection with psychotherapy methods (Fosha et al.2020).

A study previously conducted in Latvia confirmed conclusions already described in other studies of positive psychology: individuals aged 30-40 associate satisfaction with life and a sense of happiness with opportunities for personal growth, self-realization and fulfillment of internal resources - a sense of psychological flourishing (Svence, 2009).

If the individual's level of flourishing is known, it is possible to search for and analyze factors that contribute to psychological flourishing, and that lower the level of individual's flourishing. This, in turn, in the future allows to improve individual's daily performance, allows to develop support mechanisms that can help individuals to work and to live their lives fully and with full return, optimally realizing their potential.

During this study four flourishing measuring instruments were adapted. At first all instruments were translated and mathematically statistically tested, the internal consistency of all of them are high. To test whether the selected measuring instruments measure the same concept, the convergent validity was made. It was concluded that all measuring instruments have a high convergent validity - the instruments measure the same psychological phenomenon. However, it was found that PERMA-profiler (Buttler \& Kern) uses a multi-level differentiation algorithm for respondents, that allows identify respondents by their level of flourishing more accurately.

\section{Description of the Construct}

The first modern psychologist that used the concept flourishing to describe a high level of psychological well-being was Corey Lee M. Keyes. He was using representative sample of adults in the United States $(n=3032)$, Keyes divided adults into two groups: free of mental disorders or psychologically flourishing and moderately mentally healthy or psychologically languishing (Keyes, 2002). The Keye's conceptualization of flourishing is based on the idea that person's well-being is formed from three components: emotional well-being, psychological well-being, social well-being (Keyes, 2005).

Keye's ideas were developed by Felicia A. Huppert and Timoty T.C. So. By taking the opportunity to join the European Social Survey 2006/2007 they conducted the first cross-border flourishing study (Huppert et al., 2009). Although Huppert and So referred to Keyes, they chose to develop a different theoretical and conceptual framework for the concept (Huppert \& So, 2013). Huppert's and So's theoretical definition of the concept of flourishing is based on the mirror principle - an internationally accepted method for diagnosing mental disorders and illnesses. The mirror principle requires to identify the opposite set of symptoms. The authors assume that the opposite phenomenon to psychological flourishing is clinical depression and generalized anxiety disorder. By identifying the opposite symptoms of mental illness, Huppert and So made a list of ten features: competence, emotional stability, involvement, meaning, optimism, positive emotions, positive relationships, resilience, self-esteem, and vitality. Six of these features are related to the characteristics of the individual, which, in the case of high rates of flourishing, must be positively addressed. In turn, four are related to the individual's ability to function in society. Huppert and So emphasize in their conceptualization the idea that it is not enough for the individual just to feel good, it is also necessary to evaluate his subjective estimation of how well he copes with daily life activities as well (Huppert et. al, 2011).

One of the conceptualizations of flourishing concept is Flourishing scale, developed in 2010 by Ed Diener and colleagues (Diener et al., 2010). The group of authors chose not to use already existing measuring instruments but created their own. They wanted to create a very short questionnaire and to include some aspects of psychological well-being not previously included in any scale. Authors summarized previous research studies and theoretical reflections. An engagement dimension was added, based on Csikszentmihalyi works. The dimension of meaning was taken from Seligman, 
and the dimension of optimisms was taken from Peterson and Seligman (Diener et. al., 2009).

For now, the last conceptualization was created PERMA by Seligman. It looks at the concept of flourishing in five dimensions: positive emotions, engagement, positive relationships, meaning and achievements (Seligman, 2011). Basing on the model proposed by Seligman, Butler and Kern developed a corresponding measuring instrument - PERMA-profiler (Butler et al., 2016).

Only three dimensions are included in all conceptualizations of the concept described, they are:

- positive relationships - an individual is able to establish and maintain close and warm relationships with other individuals, is able to successfully cooperate with others and being with others brings him joy.

- engagement or interest - the individual is involved and carries out on a daily basis such activities, which cause him pleasure and joy, which he willingly does.

- meaning - an individual has an understanding and an idea of the meaning of his actions, the meaning and significance of his life.

In addition to these, each conceptualization considers another theoretically important dimension. Diener, Huppert and So and Keyes as an important dimension of concept put the dimension of acceptance and self-esteem. Huppert and So, Keyes and Seligman consider the presence of positive experiences or positive emotions in everyday life to be important. Diener, Huppert and So and Seligman also are paying attention to one's sense of competence - an individual's confidence in their knowledge and ability to function effectively. The authors also associate the concept of flourishing with dimensions that other authors do not consider Keyes - interpersonal or social dimension, Huppert and So - optimism, resilience, and vitality, Diener - social contribution.

The aim of the research was to study the content of flourishing concept and psychometric parameters of all of four available flourishing measurement methods.

\section{Research Methodology}

The research procedure included the comparison of all four measuring instruments, randomized sampling, survey with all four questionnaires, calculation of convergent validity of questionnaires, analysis of individual's socio-demographic indicators, planning to find possible correlations and answering the research question - whether flourishing level is due to age groups, gender or education.

Currently there are four different methods of measuring psychological flourishing created by four different researchers: Keyes, 2005, Huppert and So, 2013, Diener et al., 2009, Butler and Kern, 2016. Table 1 describes these four contents and methods of measuring flourishing of different authors. One of the proposed tools is one-dimensional (Diener), the other three consider concept of flourishing as a set of several dimensions. Also, one of the tools (Diener) gets the result by mechanically counting the points, while the others need to use the key to get the results.

\section{Table 1}

Comparison of Psychological Research Methods Used in the Study

\begin{tabular}{lcccc}
\hline & $\begin{array}{c}\text { Mental Health } \\
\text { Continuum Short } \\
\text { Form (Keyes, } \\
\text { 2005) }\end{array}$ & $\begin{array}{c}\text { Huppert and So's } \\
\text { conceptual model } \\
\text { (Huppert \& So, } \\
\text { 2013) }\end{array}$ & $\begin{array}{c}\text { Flourishing scale } \\
\text { (Diener et al., } \\
\text { 2009) }\end{array}$ & $\begin{array}{c}\text { PERMA-profiler } \\
\text { (Butler \& Kern, } \\
\text { 2016) }\end{array}$ \\
\hline Number of items & 14 & 10 & 8 & 23 \\
Number of scales & 3 & 2 & 1 & 7 \\
Original Cronbach's alpha & .80 & .83 & .86 & .82 \\
$\begin{array}{l}\text { Cronbach's alpha in this } \\
\text { study }\end{array}$ & .91 & .83 & .83 & .85 \\
\hline
\end{tabular}

Note: $n=312$ 
OF PSYCHOLOGY

IN THE $21^{\text {st }}$ CENTURY Vol. 14, No. 2, 2020

116

Within the framework of the study conducted in Latvia, all four described measuring instruments were used. There are illustrative examples of the used tools below. Diener Flourishing scale consists of eight items, that describe important aspects of psychological functioning of individual, starting with positive relationships (My social relationships are supportive and rewarding) and continuing with awareness of one's competence (I am competent and capable in the activities that are important to me), meaning and purpose (I lead a purposeful and meaningful life) (Diener, 2010).

Corey Lee M. Keyes constructed Mental Health Continuum Short Form for measuring flourishing. This questionnaire consists of 14 items, with which the individual evaluates himself. Three items refer to emotional well-being (During the past month, how often did you feel happy), six items refer to psychological well-being (During the past month, how often did you feel that you liked most parts of your personality) and five items reflect social well-being (During the past month, how often did you feel that our society is becoming a better place for people like you) (Keyes, 2005).

Huppert and So offers a questionnaire of ten items in the form of statements (I generally feel that what I do in my life is valuable and worthwhile, In general, I feel very positive about myself). In order to consider an individual as flourishing, answers must be in the range of 4-5 points (Huppert \& So, 2011).

Buttler and Kern PERMA-profiler consists of 23 item formulates as statements. Each statement refers to any of facets of flourishing: positive emotions (In general, how often do you feel joyful?), engagement (How often do you become absorbed in what you are doing?), positive relationship (To what extent do you receive help and support from others when you need it?), meaning (In general, to what extent do you lead a purposeful and meaningful life?), achievements (How often do you achieve the important goals you have set for yourself?). Several statements together form one scale. The results are calculated both for each PERMA-profiler scale and for the whole profile together.

During the study convergent validity of all measuring instruments was calculated (Table 2). The calculation shows that relations between the results of different questionaries are direct - as the value of the one questionnaire increases, the values of the results of other questionaries also increase on average. The relationship is statistically significant at the high confidence level ( $\mathrm{p}<$ $.01)$. The correlation between all questionnaires is moderately close $(.5<\mathrm{r}<.7)$.

\section{Table 2}

Convergent Validity of Measuring Instruments (Spearman Correlation Coefficient)

\begin{tabular}{|c|c|c|c|c|}
\hline & $\begin{array}{c}\text { Mental Health } \\
\text { Continuum Short } \\
\text { Form } \\
\text { (Keyes, 2005) }\end{array}$ & $\begin{array}{l}\text { Flourishing scale } \\
\text { (Diener et al., } \\
\text { 2009) }\end{array}$ & $\begin{array}{l}\text { Huppert and So's } \\
\text { conceptual model } \\
\text { (Huppert, So, 2013) }\end{array}$ & $\begin{array}{c}\text { PERMA-profiler } \\
\text { (Butler, Kern, } \\
\text { 2016) }\end{array}$ \\
\hline $\begin{array}{l}\text { Mental Health Continuum } \\
\text { Short Form (Keyes, 2005) }\end{array}$ & 1 & & & \\
\hline $\begin{array}{l}\text { Flourishing scale } \\
\text { (Diener et al., 2009) }\end{array}$ & $.60^{* *}$ & 1 & & \\
\hline $\begin{array}{l}\text { Huppert and So's } \\
\text { conceptual model } \\
\text { (Huppert \& So, 2013) }\end{array}$ & $.70^{* *}$ & $.65^{\star *}$ & 1 & \\
\hline $\begin{array}{l}\text { PERMA-profiler } \\
\text { (Butler \& Kern, 2016) }\end{array}$ & $.58^{* *}$ & $.54^{* *}$ & $.64^{* *}$ & 1 \\
\hline
\end{tabular}

All questionnaires used in the study have high convergent validity. It can be concluded that all measuring instruments used in the study are designed to measure one construct. They all are valid and can be used in practical work. 
As a part of study, randomly selected respondents were asked to complete all four flourishing questionnaires. In total 312 respondents were questioned - Latvian - speaking residents of Latvia. $18.6 \%$ (58) of them are men and $81.4 \%$ (254) are women. The average age of the respondents is 41.97 years. Places of residence of the respondents cover the entire territory of Latvia - the majority of respondents live in capital Riga $(56.7 \%, 177)$ and its agglomeration $(16.7 \%, 52)$, but the respondents from larger and smaller Latvia's cities, as well as from rural areas are also represented in the sample. The majority $-76.9 \%$ (240) of the respondents have higher education (starting with higher-professional education and ending with a doctoral degree). $84.6 \%$ (264) of the respondents have indicated their nationality as Latvians, $11.2 \%$ (35) - Russian, and $4.2 \%$ (13) of the respondents have indicated other nationality.

\section{Research Results}

For each respondent, according to the key of the corresponding measure instrument, individual level of flourishing was calculated. The total results of the study in the appropriate scales and the indicators of their descriptive statistics are summarized in Table 3.

\section{Table 3}

Descriptive Statistics of Flourishing Measuring Instruments

\begin{tabular}{lcccccc}
\hline & $\boldsymbol{M}$ & $\boldsymbol{S D}$ & $\boldsymbol{A}$ & $\boldsymbol{E}$ & $\boldsymbol{M e}$ & Mo \\
\hline $\begin{array}{l}\text { Mental Health Continuum Short } \\
\text { Form (Keyes, 2005) }\end{array}$ & 60.84 & 12.26 & -.80 & .96 & 63.00 & 66.00 \\
$\begin{array}{l}\text { Flourishing scale } \\
\text { (Diener et al., 2009) }\end{array}$ & 45.06 & 5.74 & -1.04 & 1.87 & 46.00 & $45.00,47.00,48.00$ \\
$\begin{array}{l}\text { Huppert and So's conceptual model } \\
\text { (Huppert \& So, 2013) }\end{array}$ & 41.77 & 6.19 & -.66 & .56 & 43.00 & 40.00 \\
$\begin{array}{l}\text { PERMA-profiler } \\
\text { (Butler \& Kern, 2016) }\end{array}$ & 7.51 & 1.17 & -.99 & 1.55 & 7.63 & 7.50 \\
\hline$\quad$ Note: $\mathrm{n}=312$ & & & & & &
\end{tabular}

The data obtained in the study show that degree of flourishing in the sample is estimated in a wide range - from relatively low to high. At the same time, the distributions of all results have a negative coefficient of skewness - that indicates that the majority of respondents' results are higher than the sample average.

The study examined the possible relationship between respondents' socio-demographic indicators and the level of flourishing. Respondents were asked to indicate their gender, age, nationality, place of residence (capital, other city, rest of the country), education (covering all education levels accepted in Latvia - from basic education till doctoral degree) and occupation (offering to choose from a list according to classification of Central Statistical Bureau of Latvia).

As shown in Table 4, at the trend level, but reliable correlations exist between Mental Health Continuum Short Form (Keyes, 2005) results and education and occupation. In turn, according to the calculations of results of Diener's Flourishing scale (Diener et al., 2009) reliable correlations were found between the education and occupation also at the level of trends, similarly to the Keye's scale. PERMA-profiler results also correlate with the level of education. 
Relationships between Questionnaire's Results and Respondents'Socio-Demographic Indicators

\begin{tabular}{|c|c|c|c|c|c|c|}
\hline & Age & Gender & $\begin{array}{l}\text { Place of } \\
\text { residence }\end{array}$ & Education & Occupation & Nationality \\
\hline $\begin{array}{l}\text { Mental Health } \\
\text { Continuum Short } \\
\text { Form (Keyes, 2005) }\end{array}$ & .11 & .01 & -.01 & $.11^{*}$ & $-.18^{* *}$ & .02 \\
\hline $\begin{array}{l}\text { Flourishing scale } \\
\text { (Diener et al., 2009) }\end{array}$ & .06 & .04 & -.07 & $.13^{*}$ & $-.14^{*}$ & .04 \\
\hline $\begin{array}{l}\text { Huppert and So's } \\
\text { conceptual model } \\
\text { (Huppert \& So, 2013) }\end{array}$ & .11 & -.01 & -.03 & .08 & -.05 & .06 \\
\hline $\begin{array}{l}\text { PERMA-profiler } \\
\text { (Butler \& Kern, 2016) }\end{array}$ & .08 & .07 & -.04 & $.12^{*}$ & -.03 & .06 \\
\hline
\end{tabular}

The performed content analysis of constructs allows to interpret the obtained data first from the point of their content similarities and differences: Keyes' (2005), Diener's (2009), Huppert and So's (2013) differ in content and structure from Butler \& Kern's, since the latter, based on PERMA, also takes into account health and loneliness dimensions, which are essential for an individual to be considered flourishing, the other tree view flourishing in general.

This led to the creation of substantive modeling of the construct created by each author and to the studying of similar studies examining weather flourishing level correlates with education, age, gender, occupation.

\section{Table 5}

Content Comparison of Measuring Instruments According to Content of Items and Frequency of the Criterion

\begin{tabular}{|c|c|c|c|c|c|c|}
\hline 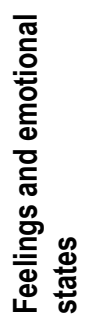 & 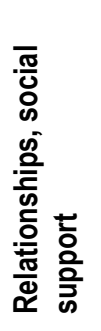 & 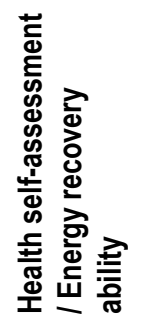 & 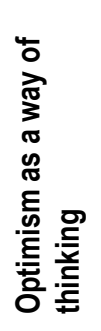 & 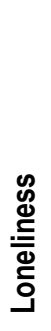 & 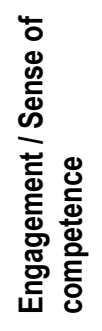 & 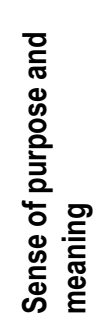 \\
\hline 1 & 6 & 0 & 1 & 0 & 2 & 2 \\
\hline 1 & 2 & 0 & 1 & 0 & 2 & 1 \\
\hline 1 & 2 & 1 & 1 & 0 & 3 & 1 \\
\hline 9 & 2 & 1 & 1 & 1 & 2 & 3 \\
\hline
\end{tabular}

As the content analysis in Table 5 shows, feelings and emotional states are not mentioned in other measures but Butler and Kern's (2016) PERMA-profiler, which, unlike others, also has an indicator of health and loneliness. In terms of content, also the frequency of accents on relationships as one of the flourishing indicators differs, for example, Keyes' form emphasizes satisfaction with relationships and social support. 
There are numbers of similarities between questionnaires as well, for example, such as a sense of purpose and a sense of meaning in the context of overall life satisfaction, as relationships with others. The criterion of engagement in activities and a sense of competence corresponds too.

\section{Discussion}

Only a few studies have shown correlation between life satisfaction and gender, but results often are contradictory, for example in an international study of 41 countries women showed higher overall satisfaction rates (Haller \& Haller, 2006, as mentioned in Svence, 2016, Upmane, 2009). Clearer gender differences appear when separately positive and negative effects and psychological well-being are examined separately - women show higher rates of both positive self-esteem and negative self-esteem than men (Nolen et al., 1999, as mentioned in Svence \& Majors, 2016, Upmane, 2009). By authors there are mentioned three possible explanations of causes of such gender differences: 1) biological - emphasizing that it may be affected by hormonal fluctuations; 2) personality - related - different personality traits, behavior and cognitive styles, that may determine that women and men feel and express emotions differently; 3) social context - which authors associate with different gender roles that determinate for women to feel and express emotions as more acceptable.

In this study it was revealed that in terms of content flourishing is characterized by a sense of ability to achieve goals, self-realization, sense of the meaning of daily activities. Similarly, it has been found in other studies. Carstensen and colleagues believe that older people have learned to organize their lives in a way that strives for and achieves goals which reinforce positive emotions (Carstensen et al., 1998, as mentioned in Svence \& Seglina-Gluškova, 2014, Upmane, 2009).

Unlike other studies, this study did not show reliable and close correlation with age. It is found in other studies that subjective well-being increases with age. However, the context of the socio-economic situation in the particular country should be considered when interpreting these data. In this study no association with age was found. Complementing these explanations with an example from another study, Sheldon and Kasser emphasized that older people set for themselves more achievable and realistic goals and that achieving them brings them joy, which in turn increases their life satisfaction (Sheldon \& Kasser, 2001, as mentioned in Upmane, 2009).

This study also examined the relationship between flourishing and education. There was found a weak but credible link. Similar studies on wellbeing, where the flourishing is part of the construct, emphasize that a more significant association between life satisfaction and education is found in less developed countries and between lower-income individuals (Diener et al., 1993, as mentioned in Svence, 2009, Upmane, 2009). That is explained by the fact that a higher level of education usually leads to a higher income and thus an increase in the level of life satisfaction. Other studies also show that in poorer countries education has much greater impact on life satisfaction than in richer countries (Sousa \& Lyubomirsky, 2001, as mentioned in Svence, 2009, Upmane, 2009). Researchers agree that, within one country, those in the highest income groups consistently show higher level of well-being than the low-income population, and that the more economically developed countries are happier than the poorer ones. Taking into account the economic background of the Latvian sample (below the average), the data can be associated with less developed countries.

Correlation with education also was measured. Research studies in other countries have shown that education expands the range of human desires and expectations, and if a person cannot realize them, his well-being may decrease (Diener et al., 1999, as mentioned in Svence, 2009, Upmane, 2009). In this study also correlation was found between flourishing rates of tree questionnaires and education. That shows the higher is the level of education, the more person realizes himself and is more satisfied with himself, thus experiencing a feeling of flourishing.

Only one flourishing questionnaire found the construct health as one of the indicators of sense of flourishing. The authors of the article believe that health is closely related to the concept of flourishing, as evidenced by classical studies in positive psychology. Diener and colleagues by analyzing several studies have come to the conclusion that the way a person perceives their health has a more significant effect on the feeling of satisfaction or well-being than the objective state of health. This perception, in turn, depends on individuals' personality traits. For example, people 
OF PSYCHOLOGY

IN THE $21^{\text {st }}$ CENTURY Vol. 14, No. 2, 2020

120

with high neurotic rates report more health disorders than are not confirmed by objective health measurements (Larsen, 1992, as mentioned in Upmane, 2009).

However, only one of the questionnaires considers the health aspect. It is probably a source for future research on flourishing, also taking into account the current health problems related to the Covid-19 pandemic in the world. An important feature of flourishing is satisfaction with relationships and the sense of social support. Other studies have shown that psychological wellbeing is also associated with individual's closeness in relationships, emphasizing that the amount of relationships does not affect the level of well-being, whereas the depth of relationships affects it (Carstensen at al, as mentioned in Upmane, 2009). This means that individuals with close and tight relationships show higher level of well-being than those with bad or superficial relationships. This aspect should also be investigated in future studies on flourishing.

The indicator employment was also measured in connection with flourishing rates. Looking through some world studies was found that work plays a key role in the development and maintenance of mental health. Studies in work and organizational psychology have shown that employment promotes social ties, thus improving well-being. One of the most important indicators of the importance of work for human well-being is that people who lose their job are more likely to suffer from various types of mental health problems - such as depression, addiction, anxiety (Lucas et al., 2004, as mentioned in Svence, 2009, Upmane, 2009). Unemployed people have been shown to tend to have lower levels of well-being than employed, and it is more likely that the loss of job has a negative effect on well-being (Argyle, 1999). This study found a weak but credible correlation between flourishing rates and employment. This is based on the idea that satisfaction with the results of one's activities gives a feeling of fulfillment and flourishing.

Overall, the results of this study raise future questions about potential of this topic - to study the relationships between flourishing and other variables that currently are ambiguous, such as gender, age, subjective assessment of health. In modern psychology more and more authors that have made research on well-being have concluded that objective conditions, demographic variables and life events do not correlate with the total index of satisfaction or well-being (including flourishing) as closely as it was considered at the beginning of positive psychology. Researchers believe that all of the above factors together explain no more than $8-15 \%$ of variation of subjective well-being (Diener \& Lucas, 1999, as mentioned in Upmane, 2009). Logically, the question arises - what can explain the rest of variation, what other indicators are related to well-being? Researchers focus on personality and heredity, when looking for other factors that can better explain the issue.

\section{Conclusions and Implications}

Results of the study show that convergent validity of all four questionnaires are consentaneous in terms of content and measure the same construct - flourishing. By analyzing content of items of all questionnaires, it was concluded that flourishing is justified by such subconstructs like relationships, including the sense of social support, engagement in activities and ability to get satisfaction from them, optimistic thinking and pleasure.

It was concluded that PERMA-profiler differs by naming nine different feelings and emotional states, as well there is emphasis on the sense of purpose and meaning.

The correlation study between the level of flourishing and socio-demographic characteristics found that gender and age do not correlate with the level of flourishing in this sample, what contradicts other studies on well-being, while flourishing is a high level of it.

There is the question that arises according to this research - what can explain the rest of variation, what other indicators are related to well-being? Researchers focus on personality and heredity, when looking for other factors that can better explain the issue.

\section{References}

Butler, J., \& Kern, M. L. (2016). The PERMA-Profiler: A brief multidimensional measure of flourishing. International Journal of Wellbeing, 6(3), 1-48. https://doi.org/10.5502/ijw.v6i3.526 
Diener, E., Wirtz, D., Biswas-Diener, R., Tov, W., Kim-Prieto, C., Choi, D.-w., \& Oishi, S. (2009). New measures of well-being. In E. Diener (Ed.), Social indicators research series: Vol. 39. Assessing well-being: The collected works of Ed Diener (pp. 247-266). Springer Science + Business Media. http://dx.doi.org/10.1007/978-90-481-2354-4_12

Diener, E., Wirtz, D., Tov, W., Kim-Prieto, C., Choi, D. W., Oishi, S., \& Biswas-Diener, R. (2010). New wellbeing measures: Short scales to assess flourishing and positive and negative feelings. Social Indicators Research, 97(2), 143-156. http://dx.doi.org/10.1007/s11205-009-9493-y

Fosha, D., \& Thoma, N. (2020). Metatherapeutic processing supports the emergence of flourishing in psychotherapy. Psychotherapy, 57(3), 323-339. https://doi.org/10.1037/pst0000289

Hone, L. C., Jarden, A., Schofield, G. M., \& Duncan, S. (2014). Measuring flourishing: The impact of operational definitions on the prevalence of high levels of wellbeing. International Journal of Wellbeing, 4(1), 62-90. http://doi:10.5502/ijw.v4i1.4

Huppert, F.A., \& So, T. C. (2013). Flourishing across Europe: Application of a new conceptual framework for defining well-being. Social Indicators Research, 110(3), 837-861. http://dx.doi.org/10.1007/s11205-011-9966-7

Huppert, F. A., Marks, N., Clark, A., Siegrist, J., Stutzer, A., Vitters, J., \& Wahrendorf, M. (2009). Measuring well-being across Europe: Description of the ESS Well-being Module and preliminary findings. Social Indicators Research, 91, 301-315. http://dx.doi.org/10.1007/s11205-008-9346-0

Jankowski, P. J., Sandage, S. J., Bell, C. A., Davis, D. E., Porter, E., Jessen, M., Motzny, C. L., Ross, K. V., \& Owen, J. (2020). Virtue, flourishing, and positive psychology in psychotherapy: An overview and research prospectus. Psychotherapy, 57(3), 291-309. https://doi.org/10.1037/pst0000285

Kaliterna Lipovčan, L., Brkljačić, T., Prizmić Larsen, Z., Brajša-Žganec, A., \& Franc, R. (2018). Leisure activities and the subjective well-being of older adults in Croatia. GeroPsych: The Journal of Gerontopsychology and Geriatric Psychiatry, 31(1), 31-39. https://doi.org/10.1024/1662-9647/a000179

Keyes, C. L. M. (2002). The mental health continuum: From languishing to flourishing in life. Journal of Health and Social Behavior, 43(2), 207-222. http://dx.doi.org/10.2307/3090197

Munoz, R. T., Hanks, H., \& Hellman, C. M. (2020). Hope and resilience as distinct contributors to psychological flourishing among childhood trauma survivors. Traumatology, 26(2), 177184. https://doi.org/10.1037/trm0000224

Perera, M. J., Meade, M. A., \& DiPonio, L. (2018). Use and psychometric properties of the Flourishing Scale among adults with spinal cord injury. Rehabilitation Psychology, 63(2), 250257. https://doi.org/10.1037/rep0000184

Seligman, M. E. (2011). Flourish: A visionary new understanding of happiness and well-being (1st Free Press hardcover ed.). Free Press.

Svence, G., \& Majors, M. (2015). Correlation of well-being with resilience and age. Problems of Psychology in the 21st Century, 9(1), 45-56. http://www.scientiasocialis.lt/ppc/node/106

Svence, G., \& Majors, M. (2016). Labizjūtas saistība ar dzīvesspēku un vecumu pieaugušo izlasēs = Relation of well-being with resilience and age in samples of adults. In Latvijas Universitāte. (Latvijas Universitātes raksti $=$ Scientific Papers University of Latvia / Latvijas Universitāte; 810. sēj.) (pp. 57-68). Latvijas Universitāte. https://dspace.lu.lv/dspace/handle/7/34345

Svence, G., \& Segliņa-Gluškova, J. (2014). Dažāda vecuma sieviešu labizjūtas, pašcieņas un dz̄ivesspēka rādītāju atšķirīibas [Differences in well-being, self-esteem and vitality of women of different ages]. In Teorija praksei mūsdienu sabiedrības izglīīībā: 7. Starptautiskās zinātniskās konferences rakstu krājums = Theory for practice in the education of contemporary society: 7th International scientific conference (pp. 174-179). Rīgas Pedagoǵijas un izglìtības vadības augstskola (RPIVA).

Svence, G. (2009). Pozitī̄ā psihologija. Laime, optimisms, apmierinātība ar dzìvi, prieks [Positive psychology. Happiness, optimism, satisfaction with life, joy]. Zvaigzne ABC.

Svence, G. (2015). Dažāda vecuma pieaugušu indivīdu apzinātības, iekšējās saskaņotības un vieduma rādītāju sakarības un atškirīibas [Correlation between mindfulness, coherence and wisdom in sample of different age groups in adulthood]. In Society. Integration. Education: Proceedings of the International Scientific Conference, May 22nd-23rd, Volume 4 (pp. 244-256). Rēzeknes Augstskola. http://dx.doi.org/10.17770/sie2015vol4.348 
OF PSYCHOLOGY

IN THE $21^{\text {st }}$ CENTURY

Vol. 14, No. 2, 2020

122

Svence, G. (2015). Dzīvesspēka kategorija pozitīvās psiholoǵijas skatījumā: attīstības iespējas [Concept of resilience in positive psychology: Developmental aspects]. Zinātne.

Titova, L., Werner, K. M., \& Sheldon, K. M. (2018). Translating positive psychology [Editorial]. Translational Issues in Psychological Science, 4(3), 211-214. https://doi.org/10.1037/tps0000170

Upamane. (2009). Apmierinātību ar dzīvi prognozējošie faktori: kvantitatīva un kvalitatīva analīze [Factors predicting life satisfaction: Quantitative and qualitative analysis]. LU. https://dspace.lu.lv/dspace/ handle/7/4844

WHO (2013). WHO traditional medicine strategy: 2014-2023. https://www.who.int/traditional-complementaryintegrative-medicine/publications/trm_strategy14_23/en/

Received: October 05, 2020

Accepted: December 05, 2020

Cite as: Pakse, I., \& Svence, G. (2020). Adaptation of flourishing as positive psychology concept in Latvia. Problems of Psychology in the $21^{\text {st }}$ Century, 14(2), 113-122. https://doi.org/10.33225/ppc/20.14.113

leva Pakse Mg.sc.soc. \& Bac.psych., Student of University of Latvia in Study Program Master in Psychology, Riga, Latvia.

Guna Svence $\mathrm{PhD}$ in Psychology, Professor, University of Latvia, Faculty of Pedagogy,

(Corresponding author) Psychology and Arts, Imantas 7 līnija 1, Riga, Latvia.

E-mail: guna.svence@lu.Iv

ORCID: https://orcid.org/0000-0001-8470-1450 